\title{
BINA KARAKTER DAN AHLAK DI ERA TEKNOLOGI KOMUNIKASI DIGITAL PADA REMAJA WARGA BINTARA JAYA IV, BEKASI JAYA, BEKASI
}

\author{
Santa Lorita Simamora, Nurhayani Saragih \\ Universitas Mercu Buana
}

santa.lorita@mercubuana.ac.id

nurhayani.saragih@mercubuana.ac.id

\begin{abstract}
Abstrak
Tujuan utama kegiatan Pengabdian Kepada Masyarakat tim Fikom Kampus Jatisampurna tentang Literasi Media Melalui Penguatan Bina Karakter, Bina Sehat dan Bina Kreatif pada anak-anak Pemulung di Wilayah Bintara Jaya IV, Bintara Jaya, Kota Bekasi ini adalah : (1) Menguatkan kesadaran remaja untuk memiliki karakter sehingga mampu dalam memilih, memilah, menyaring, bahkan mengevaluasi konten media digital, (2) Menumbuhkan kesadaran menggunakan media digital secara positif (3) Meningkatkan kemampuan (literasi media) memilih, memilah, menyeleksi, mengevaluasi konten media digital yang bermanfaat. Mitra diharapkan nantinya smart dalam menggunakan media digital dan memiliki pola positif dalam menggunakan media digital. Pelaksanaan program sosialisasi dilaksanakan dalam 3 (tiga) tahapan yakni : 1) Tahap persiapan, 2) Tahap Pelaksanaan dan 3) Tahap Evaluasi. Hasil kegiatan menunjukkan tingkat partisipasi dan antusiasme tinggi dan mulai mengenal konten positif dan negatif media digital dari para Mitra . Terlihat dari sikap proaktif mitra dalam bertanya di sesi interaktif dengan pemateri.
\end{abstract}

Kata kunci: Literasi Media, Bina Karakter, Bina Kreatif, Bina Sehat

\section{PENDAHULUAN}

Sekitar 700 kepala keluarga atau 2800 jiwa pemulung tinggal di pemukiman tidak layak huni di wilayah Bintara Jaya, Kecamatan Bekasi Barat, Kota Bekasi, Jawa
Barat. Umumnya kondisi remaja dari anakanak pemulung di sana belum memperoleh akses pendidikan dan kesehatan yang layak dari pemerintah setempat, mereka dianggap penduduk tidak resmi karena tidak memiliki Kartu Keluarga dan Akte Kelahiran. Hal ini 
disebabkan orang tua remaja tersebut tidak memiliki Kartu Keluarga dan kartu identitas sebagai bukti penduduk resmi wilayah tersebut. Padahal dokumen itu harus dimiliki sebagai syarat bisa mendapat akses pendidikan dan kesehatan dari pemerintah. Dokumen tersebut dibutuhkan sebagai syarat bagi warga untuk memperoleh fasilitas Jaminan Kesehatan Nasional (JKN) serta pendidikan formal dari pemerintah.

Kondisi sulitnya akses mendapat pendidikan formal karena ketidakmampuan biaya dan minimnya minat sekolah yang akhirnya banyak menimbulkan dampak sosial dalam lingkungan anak-anak pemulung di wilayah Bintara Jaya IV, Bekasi Jaya, Kota Bekasi. Anak-anak pemulung tersebut malas sekolah, minim kesadaran dan pengetahuan agama, adab hidup yang baik, bahkan banyak pula memiliki perilaku seks tidak normal, termasuk juga minim pengetahuan tentang kesehatan dan keterampilan hidup. Kondisi ini sejatinya bukan keinginan mereka tapi karena mereka miskin membuat mereka memiliki pola pikir yang penting perut terisi. Sehingga mereka berpikir praktis dalam mencari uang untuk biaya hidup, yaitu dengan mencari barangbarang bekas yang bisa dijual.

Hal ini menjadi tanggung jawab sosial semua pihak, termasuk salah satunya adalah Perguruan Tinggi, seperti Universitas Mercu Buana. Oleh karena itu sesuai dengan
Tridharma Perguruan Tinggi, dosen Fakultas Ilmu Komunikasi mewakili institusi pendidikan Universitas Mercu Buana melaksanakan kegiatan peningkatan bina karakter, bina kreatif dan bina sehat kepada remaja warga lingkungan pemulung di Bintara Jaya IV sebagai wujud pengabdian kepada masyarakat.

Wilayah Mitra Program Kemitraan Masyarakat ini terletak di daerah Kelurahan Bintara Jaya dengan luas $234.168 \mathrm{Ha}$, Kecamatan Bekasi Barat, dengan batasbatas wilayah sebagai berikut:

Sebelah Utara : Kelurahan Bintara

Sebelah Selatan : Kelurahan Jatibening

Sebelah Timur : Kelurahan Jakasampurna

Sebelah Barat : Kelurahan Pondok Kopi, Jakarta Timur

Teridiri dari $14 \mathrm{RW}$ dan $119 \mathrm{RT}$, dengan jumlah penduduk 41.852 jiwa (20.278 lakilaki dan 21.574 perempuan) dengan 10.493 Kepala Keluarga (sumber: Data Kelurahan Bintara Jaya, Kecamatan Bekasi Barat, 2017).

Dari data di atas, warga lingkungan pemulung di Bintara Jaya IV umumnya tidak terdaftar sebagai penduduk resmi karena tidak memiliki kartu identitas dan Kartu Keluarga. Dengan kata lain para warga di lingkungan pemulung tersebut tidak PROSIDING PKM-CSR 2019 | 152 
memenuhi syarat anggota kependudukan, sehingga sulit memperoleh akses pendidikan formal dan bantuan fasilitas kesehatan seperti Jaminan Kesehatan Nasional (JKN). Berdasarkan hal tersebut, tim pengabdian kepada masyarakat Fikom Universitas Mercubuana tertarik mengadakan pembinaan karakter, pembinaan kreativitas dan pembinaan kesehatan melalui komunikasi interaktif dengan sekelompok remaja di lingkungan pemulung Bintara Jaya IV untuk menumbuhkan rasa percaya diri, menggali potensi diri dan memiliki pengetahuan melalui konten media sosial yang digunakan..

Dengan diadakan peningkatan pembinaan karakter melalui komunikasi interaktif, remaja diharapkan mampu memunculkan karakter positif dalam dirinya dan memberikan efek positif pada pengembangan mental kemandirian remaja sebagai generasi muda dan sekaligus menghargai diri sendiri atas apa yang dimiliki remaja tersebut meskipun dalam kehidupan keterbatasan ekonomi.

Peningkatan karakter positif pada kegiatan pengabdian kepada masyarakat ini dibatasi dengan judul "Bina Karakter dan Ahlak di Era Teknologi
Komunikasi Digital pada Remaja Warga Bintara Jaya IV, Kelurahan Bintara Jaya, Kota Bekasi."

Kegiatan pembinaan karakter dan ahlak dilakukan melalui komunikasi interaktif, secara tatap muka para remaja diberikan paparan menegani media sosial dan berbagai konten yang layak diakses, seperti konten-konten ilmu agama terkait ketauhidan (meyakini ke Esaan Allah Subhaana Wa Ta'aala sebagai Ilah yang hak untuk disembah), cara melakukan shalat sesuai tuntunan Rasulullah, dan kontenkonten positif lainnya. Diharapkan dengan kemampuan mengakses konten-konten tersebut para remaja semakin memiliki karakter agamais sehingga memahami kewajibannya beribadah shalat wajib 5 waktu dan takut melakukan kemaksiatan kepada Sang Khalik.

\section{METODE}

Kerangka pelaksanaan dari pengabdian masyarakat tentang pembinaan karakter dan ahlak di Era Teknologi Komunikasi Digital pada Remaja Pemulung Warga Bintara Jaya IV, Kota dengan tahapan kegiatan sebagai berikut :

\section{Pertama :}

Sebelum pelaksanaan tim akan mempersiapkan segala sesuatunya menyangkut PROSIDING PKM-CSR 2019 
teknis pelaksanaan, pendataan peserta, menyiapkan peralatan dan perlengkapan pendukung pembinaan karakter.

\section{Kedua :}

Pembinaan dilaksanakan selama 1 (satu) hari. Pada hari pelaksanaan dijelaskan langkahlangkah kegiatan pengabdian adalah sebagai berikut :

\section{Sesi I (Motivasi melalui materi):}

Merupakan ceramah tentang teknologi komunikasi digital dan konten materi positif yang dapat menjadi sumber motivasi remaja dalam membentuk karakter positif. Peserta diberi motivasi agar memiliki spirit dan pengetahuan agama dan umum dengan harapan dapat paradigma berpikir remaja tersebut.

\section{Sesi II ( Komunikasi Interaktif):}

Peserta diajak berdiskusi tentang konten media sosial yaitu pengetahuan agama dan umum yang dapat menumbuhkan kesadaran memiliki karakter positif pada remaja pemulung. Para peserta distimuli memberikan persepsi dan opini serta bertanya terkait materi yang telah diberikan.

\section{Sesi III (Evaluasi)}

Evaluasi yang dilakukan pada kegiatan pembinaan karakter yaitu dengan memberikan kesempatan peserta maju menyampaikan kembali materi pembinaan yang terserap oleh peserta. Bagi peserta yang maju diberikan reward oleh tim pengabdian berupa buku, $\mathrm{Al}$ qur'an.

\subsection{Realisasi Kegiatan}

Kegiatan pengabdian kepada masyarakat pada semester gasal tahun akademik 2018/2019 ini dilaksanakan pada :

Waktu : Ahad / 3 Maret 2019

Tempat : Rumah Harapan, Bintara Jaya IV, Bekasi Jaya

Peserta : Remaja Pemukiman Pemulung Bintara Jaya IV, Bekasi Jaya, Kota Bekasi sebanyak 20 orang.

Pelaksana : Kegiatan ini dilaksanakan oleh tim dosen Fikom Universitas Mercu Buana. Kampus Jatisampurna

\section{Tabel 1.1}

\section{Rundown Pembinaan Karakter dan Ahlak} di Era Teknologi Digital pada Remaja Warga Bintara Jaya IV, Bekasi Jaya, Bekasi 


\begin{tabular}{|c|c|c|}
\hline WAKTU & ACARA & Keterangan \\
\hline $\begin{array}{l}14.00- \\
14.10\end{array}$ & Pendaftaran Peserta & $\begin{array}{l}\text { Winda } \\
43116210005 \text { (Mahasiswi) }\end{array}$ \\
\hline $\begin{array}{l}14.10- \\
14.20\end{array}$ & Pembukaan & Winda \\
\hline $\begin{array}{l}14.20 .- \\
15.10\end{array}$ & Sesi I (Motivasi) & $\begin{array}{l}\text { Dr. Santa Lorita Simamora, } \\
\text { M.Si }\end{array}$ \\
\hline $\begin{array}{l}15.10- \\
15.25\end{array}$ & $\begin{array}{l}\text { Sesi II ( Komunikasi Interaktif } \\
\text { dengan remaja) }\end{array}$ & $\begin{array}{l}\text { Dr. Santa Lorita Simamora, } \\
\text { M.Si }\end{array}$ \\
\hline $\begin{array}{l}15.25- \\
15.40\end{array}$ & Sesi III (Evaluasi) & Monic \\
\hline $\begin{array}{l}15.40- \\
16.00\end{array}$ & $\begin{array}{lr}\text { Penyerahan Hadiah } & \text { dan } \\
\text { Kenangan-kenangan } & \text { kepada } \\
\text { peserta yang maju. } & \\
\end{array}$ & $\begin{array}{l}\text { Winda } \\
\text { Monic }\end{array}$ \\
\hline $\begin{array}{l}16.10- \\
16.15\end{array}$ & Penutup & Winda dan Tim \\
\hline
\end{tabular}

\subsection{Khalayak Sasaran :}

Sasaran strategis pada kegiatan ini adalah generasi muda yaitu remaja usia 11-14 tahun berjumlah 20 orang di Kelurahan Bekasi Jaya, Kota Bekasi.

\subsection{Metode Kegiatan}

Metode yang digunakan pada kegiatan pengabdian masyarakat ini adalah dengan metode persuasif dan interaktif menuntut peran aktif para peserta, diharapkan peserta cepat memahami materi yang disampaikan. Keunggulan metode ini adalah para peserta dapat lebih cepat

$$
\text { memahami materi yang }
$$

disampaikan.
Rincian metode pelaksanaan

yang digunakan pada kegiatan pembinaan ahlak dan karakter remaja ini adalah sebagai berikut :

1. Metode Presentasi, yang digunakan untuk menyampaikan materi karakter dan ahlak baik untuk memotivasi peserta memahami pentingnya memiliki karakter dan ahlak yang baik.

Memberikan motivasi kepada peserta tentang pentingnya memiliki karakter dan ahlak baik.

\section{Metode interakti (Tanya-jawab)}

Memberikan kesempatan bagi peserta yang merasa belum memahami materi.

3. Metode Evaluasi atas pemahaman peserta terhadap materi dengan memilih secara random salah satu peserta untuk tampil ke depab forum, mengulas materi yang telah disampaikan dan selanjutnya diberikan reward atas keberanian peserta tampil di depan forum. 
4. Tahapan Pemantauan dan Pendampingan

Tahapan ini merupakan tahapan yang dilakukan secara berkesinambungan selama satu minggu terhadap peserta yaitu dengan berkonsultasi/bertanya melalui handphone/whatsapp sehingga dapat tercapai target/sasaran dengan efektif, yaitu dapat memanfaatkan ilmu yang diperoleh untuk dijadikan sebagai dasar membentuk karakter remaja tersebut.

\section{HASIL DAN PEMBAHASAN}

\section{Hasil Pembinaan Karakter dan Ahlak} Remaja Pemukiman Pemulung di wilayah Bintara Jaya IV, Bekasi Jaya, Kota Bekasi.

\section{Definisi Karakter}

Pengertian karakter menurut Doni Kusuma (2007) adalah sebuah gaya, sifat, ciri, maupun karakteristik yang dimiliki seseorang yang berasal dari pembentukan atupun tempaan yang didapatkannya melalui lingkungan yang ada di sekitar. Selain itu Gulo (2002) menanmbahkan bahwa karakter merupakan kepribadian yang dapat dilihat dari titik moral maupun tolak etis, misalnya saja kejujuran seseorang. Biasanya karakter memiliki hubungan pada sifat-sifat yang umumnya tetap.

Beberapa penelitian di 10 tahun belakangan menemukan bahwa anak yang memiliki karakter kuat dan positif, memiliki kemungkinan sukses di Pendidikan dan pekerjaan yang lebih besar. Merujuk kepada hasil penelitian para ahli bahwa karakter kuat dan positif memiliki kontribusi besar untuk mencapai kesuksesan dalam hidup dan menangkap realitas bahwa kondisi anakanak remaja di pemukiman liar pemulung memiliki karakter yang minus maka tim Pengabdian Kepada Masyarakat Fakultas Ilmu Komunikasi Universitas Mercu Buana Kampus Jatisampurna melaksanakan kegiatan pembentukan dan pengembangan karakter para remaja tersebut bekerja sama dengan Rumah Harapan sebagai salah satu Rumah Singgah di lingkungan pemukiman pemulung di wilayah Bintara Jaya IV, Bekasi Jaya, Kota Bekasi.

\section{Meskipun kegiatan dilaksanakan} dalam waktu singkat namun antuisme para remaja tampak saat mengikuti proses pelaksanaan acara. Interaksi timbal balik terjadi antara pemateri dan peserta, walaupun masih terlihat sedikit sikap malu-

PROSIDING PKM-CSR 2019 | 156 
malu dari peserta. Pemateri menyiasati dengan menggunakan komunikasi persuasif sedemikian rupa sehingga seiring berlangsungnya kegiatan pembentukan karakter suasana komunikasi semakin cair.

\section{Defenisi Ahlak}

Kata akhlak secara bahasa berasal dari bahasa Arab "Al Khulk" yang diartikan sebagai perangai, tabiat, budi pekerti, dan sifat seseorang. Jadi akhlak seseorang diartikan sebagai budi pekerti yang dimiliki oleh seseorang terkait dengan sifat-sifat yang ada pada dirinya.

Kata akhlak menurut istilah khususnya dalam Islam diartikan sebagai sifat atau perangai seseorang yang telah melekat dan biasanya akan tercermin dari perilaku orang tersebut. Seseorang yang memiliki sifat baik biasanya akan memiliki perangai atau akhlak yang baik juga dan sebaliknya seseorang yang memiliki perangai tidak baik cenderung memiliki akhlak yang tercela.

Kata ahlak disebutkan dalam firman Allah pada ayat berikut ini:

Sesungguhnya Kami relah
mensucikan mereka dengan
(menganugerahkan kepada mereka) akhlak
yang tinggi yaitu selalu mengingatkan

(manusia) kepada negeri akhirat.(QS Shad : 46).

Akhlak sendiri dibedakan menjadi dua golongan yakni akhlak terpuji atau akhlakul karimah dan akhlak tercela atau akhlakul mazmumah.

- Akhlak Terpuji

Diantara beberapa akhlak terpuji yang seharusnya dimiliki oleh seorang muslim adalah kesopanan, sabar, jujur, derwaman, rendah hati, tutur kata lembut dan santun, gigih, rela berkorban, adil, bijaksana, tawakal dan lain sebagainya. Seseorang yang memiliki akhlak terpuji biasanya akan selalu menjaga sikap dan tutur katanya kepada orang lain dan merasa bahwa dirinya diawasi oleh Allah Subhaanahu Wa Ta'aala.

- Akhlak tercela

Akhlak tercela adalah akhlak yang harus dijauhi oleh muslim karena dapat mendatangkan mudharat baik bagi dirinya sendiri maupun bagi orang lain. Contoh akhlak tercela diantaranya adalah dusta, iri, dengki, ujub, fitnah, bakhil, tamak, takabur, aniaya, ghibah, riya dan sebagainya. Akhlak yang tercela sangat dibenci oleh Allah Subhaanahu Wa Ta'aala dan tidak jarang orang yang memilikinya juga tidak disukai oleh masyarakat. 


\section{Cara Membentuk Karakter dan Ahlak} baik

Yang dimaksud dengan sumber akhlak adalah yang menjadi ukuran baik-buruk atau mulia dan tercela. Sebagaimana keseluruhan ajaran Islam. Sumber akhlak adalah al-Qur'an dan al- Hadits, bukan akal pikiran atau pandangan masyarakat, sebagaimana pada konsep etika dan moral. Dalam konsep akhlak, segala sesuatu dinilai baik-buruk, terpuji-tercela, semata-mata karena syara " (alQur'an dan Sunnah) menilainya demikian. Bagaimana dengan peran hati nurani, akal dan pandangan masyarakat dalam menentukan baik dan buruk karena manusia diciptakan oleh Allah Subhaana Wa Ta'aala memiliki fitrah bertauhid, mengakui ke-Esaan-Nya sebagaimana dalam firman Allah : yang artinya: "Maka hadapkanlah wajahmu dengan lurus kepada agama Allah; (tetaplah atas) fitrah Allah yang Telah menciptakan manusia menurut fitrah itu. tidak ada peubahan pada fitrah Allah. (Itulah) agama yang lurus; tetapi kebanyakan manusia tidak mengetahui (Q.S. Ar-Rum : 30)”.

Al-Qur'an dan al-Hadits sebagai pedoman hidup umat Islam yang menjelaskan baik buruknya suatu perbuatan manusia. Sekaligus menjadi pola hidup dalam menetapkan mana yang baik dan mana yang buruk. Al-Qur'an sebagai dasar akhlak menerangkan tentang Rasulullah Shallallahu Alaihi Wassallam sebagai suri tauladan (uswatun khasanah) bagi seluruh umat manusia.
Pembentukan akhlak sama dengan berbicara tentang tujuan pendidikan, karena banyak sekali dijumpai pendapat para ahli yang mengatakan bahwa tujuan pendidikan adalah pembentukan akhlak. Misalkan pendapat Muhammad Athiyah alAbrasyi yang dikutip oleh Abuddin Nata 2002:5-7), mengatakan bahwa pendidikan budi pekerti dan akhlak adalah jiwa dan tujuan pendidikan Islam. Demikian pula Ahmad D.Marimba (1980:48-49) berpendapat bahwa tujuan utama pendidikan Islam adalah identik dengan tujuan hidup setiap Muslim, yaitu untuk menjadi hamba Allah, yaitu hamba yang percaya dan menyerahkan diri kepada-Nya dengan memeluk agama Islam.

Pembentukan akhlak ini dilakukan berdasarkan asumsi bahwa akhlak adalah hasil usaha pendidikan, latihan, usaha keras dan pembinaan (muktasabah), bukan terjadi dengan sendirinya. Potensi rohaniah yang ada dalam diri manusia termasuk di dalamnya akal, nafsu amarah, nafsu syahwat, fitrah, kata hati, hati nurani, dan intuisi dibina secara optimal dengan cara dan pendekatan yang tepat. Akan tetapi, menurut sebagian ahli bahwa akhlak tidak perlu dibentuk karena akhlak adalah insting (garizah) yang dibawa manusia sejak lahir. Bagi golongan ini cenderung kepada perbaikan atau fitrah yang ada dalam diri manusia dan dapat juga berupa kata hati atau intuisi yang selalu cendrung pada kebenaran. Dengan pandangan seperti ini maka akhlak akan tumbuh dengan sendirinya, walaupun tanpa bentuk atau diusahakan (ghair muktasabah). Kelompok ini lebih lanjut menduga bahwa akhlak adalah gambaran PROSIDING PKM-CSR 2019 
batin ini tidak akan sanggup mengubah perbuatan batin.

Akhlak merupakan hasil dari pendidikan, latihan, pembinaan dan perjuangan keras dan sungguh-sungguh. Akhlak manusia itu sebenarnya boleh diubah dan dibentuk. Orang yang jahat tidak akan selamanya jahat, seperti halnya seekor binatang yang ganas dan buas bisa dijinakkan dengan latihan dan asuhan. Maka manusia yang berakal bisa diubah dan dibentuk perangainya atau sifatnya. Oleh sebab itu usaha yang demikian memerlukan kemauan yang gigih untuk menjamin terbentuknya akhlak yang mulia. Di sinilah dosen dan mahasiswa Fakultas Ilmu Komunikasi Universitas Mercu Buana Kampus Jatisampurna, mengambil bagian berkontribusi membentuk ahlak anakanak pemulung di wilayah Bintara Jaya IV, Bekasi melalui kegiatan pembinaan karakter dan ahlak dalam wujud literasi media.

\section{Konten Media Sosial}

Konten media sosial merupakan segala bentuk konten atau isi dalam sebuah $\underline{\text { media }}$ di dunia maya saat ini seperti blog, wiki, forum diskusi, chatting, tweet, podcasting, pin, gambar digital, video, file audio, iklan _ hingga berbagai bentuk konten media lainnya yang terbentuk melalui buatan dari para pengguna sistem atau layanan online yang seringkali dilakukan lewat sebuah situs $\underline{\text { media sosial. }}$.

Konten dalam Bahasa Inggris disebut dengan content, merupakan informasi yang tersedia baik itu melalui media atau produk elektronik dan disampaikan melalui berbagai medium seperti internet, televisi, CD audio, atau acara langsung seperti konferensi dan pertunjukan panggung. Konten menjadi istilah yang digunakan untuk mengidentifikasi dan mengkuantifikasi berbagai macam format dan genre informasi sebagai komponen nilai tambah media.

Bertebarannya konten di media sosial sendiri marak terjadi di 2005. Konten media kini begitu mudah diperoleh dari smartphone baik itu yang bentuknya penyelesaian masalah, berita, gosip, penelitian, dll.

Konten media kini menjadi produk yang sangat popular seiring meningkatnya jumlah pengguna media sosial dan situs-situs web yang menyediakan konten informasi berupa tulisan, gambar, atau video untuk sesama penggunanya.

Ada berbagai jenis isi atau konten media yang dibuat oleh pengguna situs online seperti forum internet yang dibuka dengan tujuan untuk memberikan manfaat pada orangorang agar dapat berdiskusi tentang topik yang berbeda-beda dan blog (blogger, tumblr, wordpress) yaitu layanan yang dimanfaatkan pengguna untuk mengepost tentang topik atau permasalahan penting tertentu.

\section{Pembahasan}

PROSIDING PKM-CSR 2019 
Dari kegiatan pengabdian masyarakat yang berupa pembinaan karakter remaja dari putra-putri pemulung di wilayah Bintara Jaya IV terlihat semangat dan antusias peserta untuk mennyimak uraian materi dari nara sumber. Hal ini mereka tuangkan dalam "Kesan-Kesan Peserta Pembinaan Karakter"

$$
\text { Pembinaan karakter melalui }
$$
penyuluhan mendapat sambutan baik dari peserta dan para relawan Rumah Harapan. Peserta secara spontan dengan gaya remajanya menyampaikan ucapan terima kasih karena ada pihak yang peduli yaitu (Universitas Mercu Buana yang diwakili Fakultas Ilmu Komunikasi) terhadap pembentukan karakter mereka untuk berubah lebih baik. Selanjutnya pihak Rumah Harapan dan peserta remaja mengharapkan bisa dilakukan kegiatan serupa secara berkelanjutan.

Karakter dan ahlak positif belum maksimal dimiliki remaja putra-putri di wilayah pemukiman pemulung Bintara Jaya IV, Bekasi Jaya, Kota Bekasi meskipun telah ada rumah singgah seperti Rumah Harapan di wilayah tersebut yang membantu mendidiki para remaja tersebut secara informal. Diperlukan banyak tehnik pembinaan karakter dan ahlak para remaja di wilayah tersebut, antara lain melalui komunikasi interaktif dipaparkan kepada para remaja cara mencari mempelajari konten- konten berupa materi agama untuk membentuk karakter dan ahlak positif di media sosial seperti you tube dan google. Tehnik mencari konten dan mempelajari materi tentang agama mudah dian Teknik tersebut relatif lebih mudah asalkan tepat memasukkan key word yang dimaksud.

Dalam pelatihan mencari konten positif terkait materi pembentukan karakter dan ahlak positif melalui media sosial mebutuhkan handphone yang memiliki kuota internet dan layar serta proyektor untuk menampilkan materi. Para peserta dipinjamkan handphone dan dipandu oleh mentor secara bergantian. Diajarkan memasukan key word yang tepat saat berselancar di google.

\section{KESIMPULAN}

Bagaimana menumbuhkan ahlak baik pada remaja khusunya remaja di lingkungan pemulung Bintara Jaya IV bukanlah pekerjaan mudah dan sesaat. Dibutuhhkan kontribusi dan sinergi banyak pihak dan kegiatan berkelanjutan.

Dari kegiatan pembinaan karakter dan ahlak pada remaja di lingkungan kumuh pemulung Bintara Jaya IV dibutuhkan kegiatan semisal yang berkelanjutan demi membentuk generasi penerus bangsa yang memiliki PROSIDING PKM-CSR 2019 $\quad 160$ 
karakter dan ahlak positif. Lebih rinci kesimpulannya adalah seperti berikut::

\section{Materi Pembinaan karakter dan} ahlak yang disampaikan secara sederhana yang bertujuan membuka kesadaran para remaja pemulung pentingnya memiliki karakter dan ahlak positif dan konten pesan terkait pembentukan karakter dan ahlak positif dapat diakses melalui media digital seperti youtube. Remaja merespon baik muatan kegiatan pengabdian.

\section{Materi Pembinaan karakter dan} ahlak diberikan sederhana dan mudah dimengerti peserta karena berorientasi pada kapasitas dan kebutuhan remaja di lingkungan pemulung, sehingga terlihat peran peserta bersemangat dan antusias mengikuti penyuluhan pembinaan karakter dan ahlak, ini tergambar dari "Kesan dan Pesan" yang peserta sampaikan.

\section{UCAPAN TERIMA KASIH}

Alhamdulillah, puji syukur selalu kami panjatkan atas Rahmat dan karunia Allah Subhaanahu Wa Ta,aala tim Pengabdian Kepada Masyarakat Fakultas Ilmu Komunikasi, Program Studi Ilmu Komunikasi Universitas Mercu Buana Kampus Jatisampurna, Bekasi telah melaksanakan dan menyelesaikan laporan pengabdian ini dengan judul "Literasi Media Melalui Penguatan Bina Karakter, Bina Sehat dan Bina Kreatif pada anak-anak Pemulung di Wilayah Bintara Jaya IV, Bintara Jaya, Bekasi. ”.

Kami mengucapkan terima kasih yang sebesar-besarnya kepada ibu Dr. Inge Hutagalung.,M.Si sebagai Kepala Pusat PPM Universitas Mercu Buana yang telah memberikan pengarahan, bapak Ranto Sihombing S.Pd selaku Koordinator Rumah Harapan Kelurahan Bintara Jaya IV, Bintara Jaya, Bekasi Jaya, Kota Bekasi yang memfasilitasi tempat terselenggaranya kegiatan pengabdian sekaligus sebagai mitra yang mendukung tim pengabdian. 